\title{
Bakır Toksisitesinin Bitkilerde Fizyolojik, Morfolojik, Biyokimyasal ve Transkripsiyonel Düzeydeki Etkileri
}

\author{
Duygu KAFKASYALI
}

\author{
Sorumlu yazar: duyguere1997@gmail.com
}

\section{Başkent Üniversitesi, Fen Edebiyat Fakültesi, Moleküler Biyoloji ve Genetik Bölümü, ANKARA}

Orcid No: 0000-0002-5134-1046 / duyguere1997@gmail.com

\begin{abstract}
Öz: Bakır $(\mathrm{Cu})$ tüm canlılar için gerekli bir metaldir. Bitkilerde bakır, birçok metalo-protein için temel bir kofaktördür ve çeşitli biyokimyasal ve fizyolojik süreçlere katıılır. Ancak farklı konsantrasyonlarda toksik etki oluşturabilir. Bitkiler genelde bakır toksisitesine çok duyarlıdır. Dokulardaki bakır seviyesi normal seviyelerden biraz daha yüksek olduğunda metabolik bozulmalara sebep olurlar ve bitkinin büyümesini engellerler. Yüksek konsantrasyondaki bakır, çok sayıda enzimi inhibe etmektedir; fotosentez, pigment sentezi ve zar bütünlüğü dahil olmak üzere bitki biyokimyasını etkiler. Hücrede biriken bakır, membran lipidlerini içeren peroksidasyon zincir reaksiyonunu başlatan serbest radikallerin üretimine yol açar ve fotosentetik elektron taşınmasının engellenmesine neden olur. Aşırı bakır, reaktif oksijen türlerini (ROS) artırarak bitkilerde oksidatif strese neden olabilir. Bakır, hücresel solunum, yağ asidi ve protein metabolizması ve nitrojen fiksasyonu da dahil olmak üzere bitki fizyolojisi üzerinde geniș bir etkiye sahiptir. Bitkisel büyümede etkili bir inhibitördür ve genellikle yaşlanma semptomlarına neden olur. Bu çalışmada; yüksek konsantrasyondaki bakırın, bitki morfolojisi, fizyolojisi ve biyokimyası üzerindeki etkilerinin yanı sıra, transkripsiyonel seviyede de etkileri incelenmiştir.
\end{abstract}

Anahtar Kelimeler: Bakır toksisitesi, Transkripsiyonel faktörler, ROS

\section{Physiological, Morphological, Biochemical and Transcriptional Effects of Copper Toxicity in Plants}

\begin{abstract}
Copper $(\mathrm{Cu})$ is an essential metal for all living things, in plants copper is an essential cofactor for many metal-proteins and participates in various biochemical and physiological processes. However, it may produces toxic effects in different concentrations. Plants are generally very sensitive to copper toxicity. When the copper level in the tissues is slightly higher than normal levels, they cause metabolic disruptions and inhibit the growth of the plant. High quantity of copper may to lead the inhibition prohibition of many enzymes; it influences plant biochemistry, consisting of photosynthesis, pigment synthesis, and membrane stability. Copper that accumulates in the cell leads to the generation of free radicals triggering the peroxidation chain reaction including membrane lipids and causes the inhibition of photosynthetic electron transportation. Excess copper may lead to oxidative stress in plants by increasing reactive oxygen species (ROS). Copper has a broad effect on plant physiology, including its interaction with fatty acid and protein metabolism, inhibition of cellular respiration and nitrogen fixation. It is an efficient inhibitor of vegetative growth and often causes symptoms of senecence. In this study; in addition to the effects of high concentrations of copper on plant morphology, physiology and biochemistry, its effects at the transcriptional level were also studied.
\end{abstract}

Keywords: Copper toxicity, Transcription factors, ROS

\section{Giriș}

Bakır $(\mathrm{Cu})$, atom numarası 29, atom kütlesi $63.5 \mathrm{~g} \mathrm{~mol}^{-1}$ ve yoğunluğu 8.96 $\mathrm{g} / \mathrm{cm}^{3}$ olan kahverengi bir geçiş metalidir ve ağır metallerden biridir. Bakır, ikili doğası olmasından dolayı bitkilerde çok araştırılan bir metal olmuştur. Bakır, bitki büyümesi için gerekli olan sekiz temel mikro besin öğesinden biridir (Nazir ve ark., 2019). Birçok proteinin yapısal bir bileşeni olarak görev alır. Hücre duvarı metabolizması, fotosentetik elektron taşınması, oksidatif 
stres yanitlar1, protein sentezi, hormon sinyallenmesi, mitokondriyal solunum gibi birçok rolde görevi bulunur (Nazir ve ark., 2019; Zhang ve Li, 2019). Bakırın kolayca indirgenip yükseltgenebilmesinden dolay1 lakkaz, sitokrom c oksidaz, polifenol oksidaz, $\mathrm{Cu} / \mathrm{Zn}$ süperoksit dismutaz, amino oksidaz ve plastosiyanin gibi birçok enzimde kofaktör görevi görür (Nazir ve ark., 2019; Zhang ve Li, 2019). Kofaktör olarak bakır içeren bu enzimlerin bazıları stres koşullarında önemli bir rol oynar (Zhang ve Li, 2019). Bitkinin metabolizmasının etkili çalışmasında bakır gerekli bir mikrobesindir. Çünkü oksidatif fosforilasyon, protein trafiği ve sinyalle düzenlenmiş transkripsiyon, lipid ve demir metabolizmaları ile ilişkilendirilmiştir (Nazir ve ark., 2019; Zhang ve Li, 2019).

Bakır mikrobesin olarak hücresel fonksiyonları sağlayabilmek amacıyla optimum seviyede bitkiler için gerekirken, fazla miktarda bulunduğunda toksik olup, bitkinin birincil üretiminde ve hayatta kalmasında olumsuz etkilere neden olabilir. Eksikliği durumunda bitkinin genç yapraklarında kloroz veya farklı renklenme, büyüme ve gelişmede azalma gibi durumlar meydana gelebilir. Bitkiler $\mathrm{Cu}^{+2}$ eksikliği olan koşullarda yaşayabilir ve bu duruma dayanabilir. Ancak $\mathrm{Cu}^{+2}$ miktarı optimum seviyeyi geçtiğinde bitkilerin sahip olduğu metabolizmayı bozarak bitki için toksik duruma gelir. Fazla bakır, bitki büyümesini ve gelişimini azaltarak, topraktan besinleri emerek, pigment içeriğini, kök büyümesini ve yaprak genişlemesini azaltarak fotosentezi büyük ölçüde engeller (Lillo ve ark., 2019; Zhang ve Li, 2019). Ayrıca fazla bakır, hücresel temel bileşenlerinin (proteinler, lipidler, DNA, RNA vb.) normal işleyişini bozar (Ameh ve Sayes, 2019). Bakır elementinin $\mathrm{Cu}^{+}$ve $\mathrm{Cu}^{+2}$ olması halinde yüksek seviyede toksik reaktif oksijen türlerinin (ROS) oluşumu ve diğer hidroksil radikaller artar. Serbest kalan kökler, DNA, RNA, proteinler, lipidler gibi önemli biyomolekülleri oksitleyebilir ve yok edebilir. Proteinlerin oksidasyonunun geri dönüşü olmaması sebebiyle bitkinin biyomoleküllerindeki bu oksidatif hasarlar, oksidatif stres ve ROS için biyobelirteç olarak kullanılır (Lillo ve ark., 2019; Zhang ve $\mathrm{Li}, 2019$ ).

\section{Bakırın Bitkilerdeki Rolü}

Bakır, bitki beslenmesi için gereklidir ve hücre metabolizması için hayati önem taşıyan birçok enzim için yeri doldurulamaz bir rol oynar (Asada ve ark., 1977; Shkolnik, 1984). Bakır içeren metaloenzimlerin çoğu, $\mathrm{O}_{2}$ 'nin bir elektron alıcisı olduğu, $\mathrm{H}_{2} \mathrm{O}_{2}$ veya $\mathrm{H}_{2} \mathrm{O}^{\prime}$ ya indirgendiği redoks reaksiyonlarının katalizine katılır (Shkolnik, 1984). Genel olarak, bakır oksidaz daha yüksek bir redoks potansiyeline sahiptir, bu da $\mathrm{Cu}^{+1}$ nın stabil olduğunu ve daha yüksek redoks potansiyeline sahip bir oksidanla $\left(\mathrm{O}_{2}\right.$ gibi $)$ 
reaksiyonu teşvik ettiğini gösterir. Tripsin, lakkaz, askorbat oksidaz, monoamin ve diamin oksidaz, D-galaktoz oksidaz ve sitokrom oksidaz içinde durum böyledir (Clarkson ve Hanson, 1980).

Bitkilerde bakırın diğer önemli rollerinden biride, esas olarak yüksek kara bitkilerin kloroplastları ile ilgili olan bir bakır ve çinko enzimi olan süperoksit dismutazdır (Asada ve ark., 1977). Oksidaz fonksiyonu olmayan ana bakır redoks proteini, indirgeme kabiliyetinde fotosistem I'e (PSI) eşdeğer olan plastosiyanindir. (Clarkson ve Hanson, 1980). Bakırın fotosentezdeki rolü, sitokrom oksidazın doğal bir bileşeni olmasıyla ilişkilidir (Shkolnik, 1984).

Optimum koşullar altında kloroplastlar; yaprakta bulunan bakırının \% 35 ile 90'ını biriktirmektedir (Lastra ve ark., 1987). Bakırın çok büyük miktarı (yaklaşık yarıs1) plastosiyanin olarak kloroplastta yer alır. Bakırın tilakoidin zar yapısının korunmasında önemli bir rol oynadığı gözlenmiştir (Henriqnes, 1984; Henriqnes, 1989; Lastra ve ark., 1987).

Bakırın baklagil kökleri tarafından atmosferdeki $\mathrm{N}_{2}$ 'un simbiyotik fiksasyonu üzerinde olumlu bir etkiye sahip olduğu bilinmektedir (Shkolnik, 1984).

\section{Bitkilerde Bakır Toksisitesi}

Aşırı bakır birikimi bitki büyümesini ve metabolizmasını etkileyerek bitkide strese neden olur (Raldugina ve ark., 2016;
Baldi ve ark., 2018a; Gong ve ark., 2019; Marques ve ark., 2019). Bakır aracilı büyümenin azalması, Brassica napus (Mwamba ve ark., 2016), Mühle zostera (Buapet ve ark., 2018) ve Phaeolus vulgaris (Mwamba ve ark., 2016) gibi farklı bitki türlerinde kanıtlanmıştır. Bitki köklerine yönelik bakırın neden olduğu toksisite, toprak besinini ve su emilimini etkiler (Michaud ve ark., 2008). Bakırın bitki köklerindeki birikimi, kök gelişiminde inhibe edici bir etki göstermektedir (Michaud ve ark., 2008). Ancak, Cu ile indüklenen kök uzaması inhibisyonunun mekanizması tam olarak aydınlatılamamıştır. Bakırın toksisitesi önce köklerde meydana gelir, ardından bitkinin diğer kısımlarında çeşitli fizyolojik süreçleri etkiler; gecikmiş kök büyümesine, daha az dallanmaya, daha koyu renge, zayıf büyümeye ve daha az kalınlaşmaya neden olur (Marques ve ark., 2019; Cambrollé ve ark., 2013; Sheldon ve Menzies, 2005; Kopittke ve ark., 2011). Kökün büyümesindeki azalma genelde kök epidermisinin ayrıca dış kabuğunun yırtılmasıyla ilgilidir (Kopittke ve ark., 2011). $\mathrm{Bu}$ nedenle, aşırı bakır genellikle Triticum aestivum gibi bitkilerde fosfor eksikliğiyle ilişkilendirilmektedir (Rose ve ark., 2016). Bazı çalışmalar ayrıca bakıra maruz kalmanın bitki kökleri üzerinde hiç etkisi olmadığını veya çok az etkisi olduğunu da bildirmiştir. Örneğin; 1spanağa 
$100 \mathrm{mg} \mathrm{L}{ }^{-1} \mathrm{Cu}$ verildiğinde toplam kök ucu sayısını, kök uzunluğunu ve kök yüzey alanını değiştirmediği belirtilmiştir (Gong ve ark., 2019). Başka bir çalışmada da ıspanak kökü büyümesi hakkında benzer bulgular elde edilmiştir (Singh ve Kumar, 2016). Literatürdeki bazı kaynaklara göre; bakır stresi altında hardal köklerinin uzunluğunda, $0.75 \mathrm{mM}$ bakır uygulamasinda bir azalma görülmüştür (Yadav ve ark., 2018). Toprakta $271 \mathrm{mg} \mathrm{kg}^{1} \mathrm{Cu}$ varlı̆̆ kuru kök ağırlığında \%20'lik bir azalma olduğunu göstermiştir (Kumar ve ark., 2000). Azalmış kök büyümesinin potasyum ve fosfor alımını önemli derecede azalttığ ve bunun asıl sebebinin küçük bitki köklerinin tam gelişmiş köklere göre daha az hacimde toprak kaplamaları olduğu belirtilmiştir (Baldi ve ark., 2018a; Baldi ve ark., 2018b; Kumar ve ark., 2019; Lwalaba ve ark., 2019). Fazla bakırın, fasulye bitkilerinin genç yapraklarında antioksidan enzim sisteminin aktivitesini değiştirdiğini ve toksisitesinin bitki homeostazında bozulmaya neden olduğu bilinmektedir (Bouazizi ve ark., 2010).

Yüksek konsantrasyondaki bakırın Arabidopsis'te nitrojen alımını ve birikimini önemli ölçüde azalttığı bilinmektedir. Azot alımındaki bakır aracılı azalmanın temel olarak düşük afiniteli nitrat taşıyıcısının, nitrat redüktaz kodlamasının ve $b Z I P$ transkripsiyon faktörlerinin (TGA1 ve TGA4) aşağ1 regülasyonundan kaynaklandığ taşıyıcılarının düzenlenmesinde rol oynamaktadır (Hippler ve ark., 2018).

Bakırın hücrelerdeki birikimi, bitki pigment içeriğini olumsuz etkilemektedir. $\mathrm{Bu}$ nedenle; fotosentez süreci de olumsuz etkilenmektedir. Bazı çalışmalar, azalmış pigment içeriğinin ve bozulmuş fotosentezin bakır toksisitesini etkileyen ana faktörlerden biri olduğunu bildirmiştir (Jaime-Pérez ve ark., 2019; Lwalaba ve ark., 2019). Bakırın, fotosentetik membran pigmentlerinin ve proteinlerinin bileşimini etkileyerek fotosentetik enzimlerin sentezini inhibe ettiği bulunmuştur (Bazihizina ve ark., 2015; Silva ve ark., 2018). Yeni yapılan bir çalışmada kırk gün boyunca $100 \mathrm{mg} \mathrm{kg}{ }^{-1}$ bakıra maruz bırakılan domates bitkilerinin pigment içeriğini ve fotosentetik aktivitesini önemli miktarda azalttığı görülmüştür. Ayrıca domates bitkilerinin stomaların hareketini ve antioksidan aktivasyonunu etkilediği gösterilmiştir (Nazir ve ark., 2019). Fotosistem II (PSII) verimliliği, karbondioksit difüzyonu, ROS üretimi, elektron taşınması (Gong ve ark., 2019) ve fotorespirasyon (Baldi ve ark., 2018a; Ameh ve Sayes, 2019; Marcec ve ark., 2019) gibi bitki fotosenteziyle ilgili faktörler de bakır toksisitesinden etkilenmektedir (Ryszka ve ark., 2019). Bakıra $(100 \mu \mathrm{M})$ maruz kalmanın arpanın transpirasyon ve fotosentez hızını da büyük ölçüde azalttığ bilinmektedir (Lwalaba ve ark., 2019). 
Peltophorum dubium'da $\mathrm{Cu}$ ile kirlenmiş toprağın fotosentez, 1şık kararlılık noktası, transpirasyon, karanlık solunum frekansı, 1şık doygunluk noktası ve maksimum net fotosentez hızı gibi gaz değişim parametreleri üzerinde olumsuz bir etkiye sahip olduğunu bildirilmiştir (Marques ve ark., 2019). Son zamanlarda, Cu'ın Rhodospirillum rubrum'un pigment içerikleri üzerindeki etkisi değerlendirilmiş ve $2 \mu \mathrm{M}$ Cu'ın Rhodospirillum rubrum'un büyüme ve fotosentetik reaksiyon merkezlerinde önemli bir azalmaya neden olduğu gözlemlenmiştir (Jaime-Pérez ve ark., 2019).

Bakır, ROS oluşumunu artırarak fotosentez ve bitki pigmentlerinde toksisiteye neden olur (Gong ve ark., 2019). ROS'un fotosentetik elektron taşıma sisteminde elektron akışını etkilediği ayrıca fotosentez sürecine etki ettiği gösterilmiştir (Shahid ve ark., 2015). Aşırı miktarda hidrojen peroksit üretimi, PSII proteinindeki sentezini etkilediği bunun sonucunda kloroplasttaki membrana hasar verdiği kanıtlanmıştır (Gomes ve ark., 2014).

Bitkilerin aşırı miktarda bakıra maruz kalması, genellikle nekroz, solma, kloroz ve yavaş bitki büyümesi gibi çeşitli toksik semptomlara neden olur (Ameh ve Sayes, 2019; Marques ve ark., 2019). Bakır toksisitesinin en yaygın semptomu olarak yaprak klorozu gösterilmiştir (Michaud ve ark., 2008; Bouazizi ve ark., 2010). Kloroz, beyaz lezyon ya da lekelerle görülebilir. Bakır miktarının fazla olması durumunda yaprak uçlarında, yaprak kenarlarında nekrotik görünüme sebep olur (Bouazizi ve ark., 2010; Ameh \& Sayes, 2019).

\section{Bakırın Bitki Hücrelerine}

\section{Biyokimyasal, Fizyolojik ve Morfolojik}

\section{Etkileri}

Bitkilerde, birkaç normal aerobik biyokimyasal reaksiyonun yan ürünleri, doğal olarak hidrojen peroksit $\left(\mathrm{H}_{2} \mathrm{O}_{2}\right)$, süperoksit ve hidroksil radikalleri gibi farklı ROS formları üretir (Shahid ve ark., 2015; Du ve ark., 2019). Biyokimyasal reaksiyonlar arasinda solunum ve fotosentez de sayılabilir ve reaksiyonlar mitokondri, peroksizom ve kloroplastlarda gerçekleşir (Pourrut ve ark., 2011; Du ve ark., 2019; Shahid ve ark., 2015; Marcec ve ark., 2019). Spinacia oleracea'dan izole edilen kloroplastlarda fotosentetik elektron taşınmasının inhibisyonu gözlenmemiştir. Bunun sonucunda, bakır iyonlarının direkt elektron taşınmasına dahil olmadığı fakat fotosentetik membranda yapisal değişikliklere neden olduğu ve elektron akışının engellenmesine neden olan membran proteinine bağlandığ düşünülmektedir (Baszynski ve ark., 1982; Marcec ve ark., 2019).

Bakır, redoks aktif bir metaldir ve bitkilerdeki farklı reaksiyonlar yoluyla ROS üretimini etkilemektedir; ROS normal olan metabolik koşullarda patojenlere karşı 
savunma, hücre duvarı lignifikasyonu, gen ifadesi yoluyla apoptozun indüksiyonu ve algılanması ile stres koşullarına adaptasyon gibi temel işlevlerle ilişkilidir (Neill ve ark., 2002; Pourrut ve ark., 2011). Ayrica bitkilerde stres sinyalini, meyve olgunlaşmasını, sistemik tepkileri, yaşlanmayı ve hücre ölümünü, redoks seviyelerini, gelişmenin kontrolünü sağlar (Pourrut ve ark., 2011; Qi ve ark., 2017; Noctor ve ark., 2018; Fichman ve ark., 2019; Marcec ve ark., 2019). ROS'un da çok üretilmesi canlı hücrelerde oksidatif hasara neden olur (Krayem ve ark., 2018; Younis ve ark., 2018; Sharma ve ark., 2019). Bu yüzden oksidatif stres biyolojik metabolizmalarda kendiliğinden ortaya çıkan fizyokimyasal bir durumdur. ROS üretiminin artmasiyla DNA, proteinler ve lipidler gibi temel makromoleküllerde oksidatif hasar meydana gelir (Srinivas ve ark., 2018). Bu nedenle ROS artışı birtakım organellerin hasarına da neden olmaktadır (Shahid, 2017).

Lipidler, organellerin ve hücrelerin bütünlügünü ve bileşimini korumak, hücre zarlarını oluşturmak ve hücre metabolizması için enerji sağlamak gibi birçok biyokimyasal süreçte anahtar rol oynadıklarından çok önemli hücresel bileşenler olarak kabul edilirler. Daha yüksek ROS seviyeleri nerdeyse tüm hücresel makromolekülleri yok edebilir ve bu durum lipid peroksidasyon sürecinin başlamasına neden olabilir (Yalçınkaya ve ark., 2019). Lipid peroksidasyonu, aşırı metallerden kaynaklı ROS üretiminin bir sonucudur ve bitkideki oksidatif stresin bir göstergesi olarak kabul edilir (Kapoor ve ark., 2019). Bitkilerdeki plazma zarları, ağır metal toksisitesinin ana hedefidir (Natasha ve ark., 2020) ve ROS hücre zarı üzerinde hasarlara neden olabilir (Pourrut ve ark., 2011; Younis ve ark., 2018).

ROS üretiminin artması yă̆ asidi zincirlerindeki hidrojen atomlarına bir atak yapar böylelikle aldehitler ve lipid radikalleri oluşur. $\mathrm{Bu}$ oluşumlar sonucunda plazma zarında işlevsellik ve bütünlük bozulur. Hidrojen peroksit ve süperoksit lipid peroksidasyonunu başlatabilir ancak sadece hidroksil radikali, demir ve bakır varlığında peroksidasyonu etkileyecek kadar reaktiftir (Yalçınkaya ve ark., 2019). MDA (malondialdehit) ve TBARS (Tiobarbitürik asit reaktif maddeler), membranlardaki polidoymuş yağ asitlerinin ayrışması sonucunda ortaya çıkar aynı zamanda lipid peroksidasyonunun da bir göstergesi olarak bilinirler. Bakırdan kaynaklanan membran hasarından dolayı membranındaki geçirgenliğin artmasına ve lipid peroksidasyonuna sebep olmaktadır (Cao ve ark., 2017; Nanda ve Agrawal, 2018; Younis ve ark., 2018).

Deschampsia caespitosa'da bakırın, kök asit fosfatazı ve Silene vulgaris'te nitrat redüktaz ve fenol oksidazı inhibe ettiği 
gösterilmiştir. Bakırın hücre metabolizmasında zararlı etkisi genellikle enzim üzerinde inhibitör etki yaratmasından kaynaklanmaktadır. Olumsuz etkilerin çoğu, bakırın enzimatik aktivite için gerekli olan SH gruplarına geri döndürülemeyecek şekilde bağlanmasından kaynaklanmaktadır (Larcher, 1980).

Bakırın toksisitesi kök büyümesini ve morfolojisini büyük ölçüde etkiler çünkü kök dokularda birikme eğilimindedir ve sürgünlere aktarılabilir (Zhang ve ark., 2015). Bakır toksisitesinin genel görsel semptomları arasında kök büyümesinin engellenmesi, orta yaprakların klorozu, yaprak solması, nekrotik yaprak uçları ve kök anormallikleri sayllabilir. (Chen ve diğerleri, 2015; Jung ve ark., 2015). Aşırı bakır içeriği bitki köklerinde, kök epidermisinin bozulması, kök tüylerinin yayılmasının azalması ve ciddi kök yapısı deformasyonunu gibi semptomlar meydana getirir (Sheldon ve Menzies, 2005). Düşük konsantrasyonlarda, bakır bir bitki mikro besin maddesidir, mahsul verimi ve biyokütle düşmeye devam ederken görünür semptomlar daha az belirgin veya tespit edilemez olabilir (Marschner, 1995). Bir çalışmada bakırın Hydrangea citronella üzerindeki toksik etkisine dikkat çekerek elde edilen sonuçlardan, Cu'ın $200 \mathrm{mg} \mathrm{kg}^{-1}$ muamelesi altında bitkinin büyümesi ve kök morfolojisi için uygun olduğunu, Cu'ın 800 $\mathrm{mg} \mathrm{kg}^{-1}$ muamelesi altındaki bitkinin büyümesi ve kök morfolojisi üzerinde olumsuz bir etkisi olduğu gösterilmiştir (Marques ve ark., 2018).

Mikro besleyici bir ortamda bakırın kök büyümesi üzerinde olumlu bir etkisi vardır (Marques ve ark., 2018). Kök yüzey alanı besin emilimiyle ilgilidir ve kök hacmindeki artış, daha iyi besin emilim kapasitesine yol açar ve sonuçta bitki büyümesi üzerinde olumlu bir etki oluşturur. $\mathrm{Cu}$ muamelesi altında kök hacmindeki azalma, hücre bölünmesi ile doğrudan ilişkili kök biyokütlesinde önemli bir düşüş olduğunu gösterir (Batool ve ark., 2015). Kök büyümesindeki önemli azalmanın, ağır bir metal stresi altında kök hücre duvar kalınlığında artışa yol açan hücre bölünmesindeki azalmayla ilişkili olduğu gözlemlenmiştir (Batool ve ark., 2015). Cu toksisitesinin yaygın bir erken belirtisi de yaprak klorozudur (Garcia ve ark., 2018). Eximia okaliptüs (sar1 kan ağacı) ve Casuarina distyla (dişi meşe) gibi bitkilerde yüksek bakır toksisitesi altında kloroz gözlenmiştir (Tielle ve ark., 2015). Bakır toksisitesi ayrıca yaprak morarmasıyla da ilişkili olabilir ancak tüm bitkilerde aynı etkiyi göstermeyebilir (Mostofa ve Fujita, 2013). Bakır stresi altındaki yaprak alanındaki azalma, ksilemde lignin birikimine bağlanabilir, bu da sonunda hücre duvarının kalınlaşmasına ve sertleşmesine yol açar. Bu etkiyle hücre elastikiyeti azalır, hücre gelişimi ve yaprak büyümesi üzerinde 
olumsuz sonuçlara neden olur (Garcia ve ark., 2018). $\mathrm{Cu}$ toksisitesi altında, misır ve Rodos otunda nekroz gözlenmemiştir (Smilde, 1981).

Tüm bu çalışmalardan bakır uygulamasının kök uzunluğu, dal uzunluğu ve yaprak alanı gibi morfolojik parametreleri azalttığı sonucuna varılabilir. Ayrıca bakır stresi altında yapraklarda kloroz, nekroz ve morarma görülmüştür. Bitkiler özellikle organik toprakta büyüdüğünde bitkilerin bakırı absorblama olasılığı daha düşüktür, dolayısıyla bakırın toksisitesini büyük ölçüde azaltır (Sheldon ve Menzies, 2005). Yulaf, mısır, çavdar, marul, sspanak ve fasulye gibi bitki türlerini içeren bir deneyde Cu'ın toksisitesi $\mathrm{Cd}$ ve Ni'den sonra üçüncü sırada yer aldığ gözlemlenmiştir (Smilde, 1981). Metal içeriğinin kritik düzeyde olması çamurdaki metal miktarının varlığının bir göstergesidir. $\mathrm{Bu}$ koşullar altında, çamurdaki bakır içeriği 1000-1500 ppm'e yakın olduğunda, metal emilimindeki ve yer değiştirmedeki azalmayı yansıtan büyüme inhibisyonu gözlemlenebilir. Bununla birlikte, kritik düzeydeki metal seviyesi yaprak konsantrasyonunda ifade edildiğinde, $\mathrm{Cu}$ en toksiktir ve büyümeyi engelleyen konsantrasyon, kadmiyum (Cd) ve nikel (Ni)'in etki ettiği konsantrasyondan 3-4 kat daha düşüktür. Bu koşullar altında, bakırın toksisitesi genellikle ilk sirada yer alır: bakırın 10 metal arasında en toksik olduğunu ve kültür ortamında yetiştirilen çavdarın düşük konsantrasyonlarda bakıra maruz kalması kök büyümesi üzerinde etkilidir (Wong ve Bradshaw, 1982). Bakırın çözelti kültüründe bitkiler için yüksek toksisitesi birkaç türde gözlemlenmiştir; mısır büyümesi 0.06 ppm'lik bakır tarafindan engellenir (Stiborova ve ark., 1986b). 0.6 ppm bakır, pirinç köklerinin ve filizlerinin büyümesini ve çimlenmeyi tamamen engeller (Mukherji ve Gupta, 1977). Ortamdaki 1 ppm bakırın, Agaricus sylvestris'in kök büyümesini inhibe ettiği gözlemlenmiştir (Hogan ve Rauser, 1981).

Bitki toprağındaki veya kültür ortamındaki tomurcuk büyümesiyle karşılaştırıldığında, tomurcuk büyümesinin $\mathrm{Cu}$ toksisitesine karşı daha duyarlı olduğu belirtmektedir. $\mathrm{Bu}$ durumun, tomurcuk translokasyonunun azalmasına bağlı olarak köklerde bakır birikmesinin bir sonucu olduğu düşünülmektedir (Baszynski ve ark., 1982; Stiborova ve ark., 1986a; Gupta ve Mukherji, 1977). Bakır toksisitesine kök uzamasının kök çimlenmesine nazaran daha duyarlı olduğu gösterilmiştir (Hogan ve Rauser, 1981).

Bakır yalnızca bitkisel büyümeyi engellemez. Literatüre göre, bakır önemli bir üreme sürecini de inhibe edebilmektedir. Örneğin Kızılçamda (Pinus resinosa), ortamdaki $\mathrm{Cu}$ içeriğgi 0.04 ve 0.23 ppm ölçüsüne kadar düşüktür, bu da polen tanesi çimlenmesinde ve polen tüpünün 
uzamasında \%10'luk bir azalma ile sonuçlanır ayrıca 1.13 ppm'de her iki işlemin de tam olarak engellenmesi gözlenmiştir (Chaney ve Strickland, 1984).

Luschnathiana bitkisi Brezilya'da bakırla kirlenmiş sulak alanlarda bulunan ve sele karşı oldukça toleranslı bir türdür. Bitkiler, farklı konsantrasyonlarda bakır içermekte olan tamamen besleyici olan bir çözelti içerisinde yetiştirilmiştir. Büyüyen iki yaprakta ve $0.16 \mathrm{mmol} \mathrm{Cu} \mathrm{L}^{-1}$ uygulanan bitki köklerinde $\mathrm{Cu}$ toksisitesi belirtileri gözlenmiştir. Yapraklardaki bakır; epidermis, mezofil, palizat parankiması ve parankimanın hücreler arası boşluğunun kalınlığında önemli değişikliklere neden olduğu görülmüştür. Ayrıca bu metal, tilakoid zarlarda düzensizliklere, kloroplastta iç ve diş zarların yırtılmasına, mitokondride değişikliklere, parankima ve hücre çeperi boşluklarında elektrolit materyallerinin birikmesine neden olmuştur. Nişasta granüllerinin kaybolduğu ancak $\mathrm{Cu}$ toksisitesine göre plastid sayısında artış gözlenmiştir. Kökte epidermis yok olur, hücreler arasındaki boşluk azalır ve diş korteksteki ilk hücrenin morfolojisi önemli ölçüde değişir. Hücre çeperi ve endodermanın parçalandığ1 gözlemlenmiştir. Mineral besin analiziyle, köklerde daha yüksek bakır birikimi ve dallarda makro ve mikro besin elementlerinin biriktiğini göstermiştir. $\mathrm{Bu}$ nedenle, kök morfolojisindeki ve ince yapısındaki değişiklikler, bakır toksisitesinin neden olduğu zar ve endodermanın yapısal bozulmasına bağlı olarak, farklı besin maddelerinin emilimine ve kökten sürgünlere taşınmasına yol açacağ düşünülmektedir (Stiborova ve ark., 1986a; Marques ve ark., 2018). Hymenaea courbaril L.'nin aşırı bakır toksisitesi altında kök morfolojisi ile ilgili yapılan çalışmada, topraktaki yüksek bakır konsantrasyonu nedeniyle kök uzunluğu, özgül yüzey alanı, ortalama çap, kök hacmi, kuru biyokütle ve özgül kök uzunluğu azalır. Bakır, yapraklarda bulunan metabolik bağlamda en aktif dokuları korumak için tolerans mekanizması olarak $800 \quad \mathrm{mg} \quad \mathrm{kg}^{-1}$ konsantrasyona kadar köklerde birikir. Bu konsantrasyondan fazlasının $H$. courbaril köklerinin büyümesini baskıladığ görülmüştür. Ancak bu konsantrasyona kadar bu bitki topraktaki fazla bakırı tolere edebilir, bu da metalle kirlenmiş alanların geri dönüştürülebileceğini göstermektedir (Marques ve ark., 2018).

\section{Bakırın Transkripsiyonel}

\section{Seviyede Gen İfadesi Üzerine Etkisi}

Gen ifadesinin düzenlenmesi, bitkilerde büyüme, gelişme, farklılaşma, metabolik düzenleme ve çevreye adaptasyon gibi birkaç temel süreç için gereklidir (Verma, 1992). Herhangi bir gen ifadesinde transkripsiyon, gen ifadesinin düzenlenmesinde önemli bir rol oynar. Transkripsiyon, hücreler arası ve hücre dış1 
sinyallere aracılık eden çok sayıda transkripsiyon faktörü tarafından kontrol ediliyor gibi görünmektedir. $\mathrm{Bu}$ nedenle, transkripsiyon faktörlerinin analizi, gen ifadesi mekanizmalarını anlamak için gereklidir ve bitki biliminin tüm alanlarında önemlidir (Verma, 1992). DNA'daki genetik bilgiyi okuyup ifade edilmesinde görevli protein gruplarından biri olan transkripsiyon faktörleri, bir genin transkripsiyonuna aktivator veya repressör olarak etki eder. (Lee ve ark.; 2000, Verma, 1992; Gökdemir, 2019). COPT1 geni embriyolarda, trikomlarda, stomalarda, polenlerde ve kök uçlarında ifade edilir. Bakır, sınırlı koşullar altında büyüme için gerekli olduğundan, bakır kazanımı ve birikiminde önemli bir fizyolojik rol oynar. Kök uzaması ve polen gelişimine olan katkısı da açıklanmıştır (Sancenón ve ark., 2004). COX17, biyotik ve abiyotik stres altında, özellikle bakır toksisitesinde organel işlevini sürdürmek için gerekli olan spesifik enzimlerin aktivitesini artırmaya yardımcı olur (Balandin ve Castresana, 2002).

$\mathrm{Cu}$ eksikliği sirasında $\quad S P L 7$ (Squamosa PROMOTER BAĞLAYICI PROTEIN LIKE7) ve CRR1 (BAKIR RESPONSE REGULATOR1) gibi iki transkripsiyon faktörü hedeflerinin promoterlerinde $\mathrm{Cu}$ eksikliğine duyarlı elemanlara (5'-GTAC-3') bağlanarak gen ifadesini düzenler (Sommer ve ark., 2010; Yamasaki ve ark., 2009; Quinn ve ark.,
2000; Birkenbihl ve ark., 2005; GarciaMolina ve ark., 2014; Kropat ve ark., 2005). Yapılan transkriptom analizleri, SPL7'nin demir (Fe) / Cu redüktaz oksidazların, FRO4 ve FRO5'in ve birlikte yüksek afiniteyi oluşturan bakır taşıyıcı ailesinin üyelerinin, (COPT1 ve COPT2) birkaç $\mathrm{Cu}$ taşıyıcısının ekspresyonu için gerekli olduğunu ortaya koymuştur (Bernal ve ark., 2012; Gayomba ve ark., 2013; Jung ve ark., 2012; Yamasaki ve ark., 2009). SPL7 ile düzenlenen genler arasinda, COPT6, YSL2 ve YSL3 ve $\mathrm{Cu}$ şaperon $\mathrm{CCH}$, birlikte Cu'in fotosentetik dokulara taşınmasına ve yaşlanmanın ardından bakırın biriktirildiği yerlerden az olan yerlere hareketlendirmesine katkıda bulunur (Bernal ve ark., 2012; Gayomba ve ark., 2013; Jung ve ark., 2012; Yamasaki ve ark., 2009; Chu ve ark., 2010; Himelblau ve ark., 1998; Mira ve ark., 2001; Himelblau ve Amasino, 2001). Bakırın hücre içi dengesinde SPL7'nin önemli rolü olmasının bir kanıtı olarak yapılan bir çalışmada SPL7 mutantlar, büyüme ortamına $\mathrm{Cu}$ eklenmedikçe daha az $\mathrm{Cu}$ biriktirdiği ve daha yavaş geliştiği görülmüştür (Bernal ve ark., 2012; Yamasaki ve ark., 2009; Gayomba ve ark., 2013). Bakırın bitki verimliliğindeki rollerinin bilinmesine rağmen bakırın üremeyle olan ilişkisini belirleyen moleküler belirleyicilerle ilgili bilgiler çok azdır. Yapılan çalışmalara göre, COPT1, СОРT2, СОРТ3 ve COPT6 bakır taşıyıcılarını kodlayan genlerin 
Arabidopsis'in polen tanelerinde ifade edildiği bildirilmiştir (Sancenón ve ark., 2004; Gayomba ve ark., 2013; Jung ve ark., 2012; Bock ve ark., 2006). AtCOPT3 polen gelişiminde erken ifade edilirken, AtCOPT1 daha sonraki aşamalarda ifade edilir (Bock ve ark., 2006). AtCOPT1 antisens bitkileri, $\mathrm{Cu}$ sınırlı koşullar altında polen anormallikleri sergiler ancak bu durumun bakır takviyesi ile düzelebileceği bildirilmiştir (Sancenón ve ark., 2004).

Bakırın fazla miktarda uygulanmasının birincil kök büyümesini inhibe ettiği gösterilmiştir (Pasternak ve ark., 2005; Chen ve ark., 2011; Bernal ve ark., 2012). Bakır aracilı oksinin yeniden dağılımının, birincil kök uzamasındaki $\mathrm{Cu}$ aracılı inhibisyonundan sorumlu olduğu gösterilmiştir. Bunu düzenleyenin PINFORMED1 (PIN1) olduğu, ancak PIN2 veya AUXIN1 (AUX1) olmadığ gösterilmiştir (Yuan ve ark., 2013). CAMTA ve $Y A B B Y$ genlerinin bitkilerin ağır metal stresi altında potansiyel genetik belirteç olarak kullanılabileceği gösterilmiştir. Bakır konsantrasyonunun Akman-98 fasulye çeşidinde gen ifade düzeyinde artışa neden olurken Önceler-98 fasulye çeşidinde ise azalışa neden olduğu gözlemlenmiştir. Önceler-98 çeşidinde YABBY-7 genine ait ifade seviyesinde azalış, CAMTA-4 geninin ifade düzeyinde ise artış gözlemlenmiştir. $C A M T A$ ve $Y A B B Y$ gen aileleri bu çalışmada stres uygulandiktan sonra, iki farklı fasulye çeşidinin gen ekspresyon profillerinin farklı süreçleri, tolerans ve adaptasyon mekanizmalarının farklı evrimsel süreçleri izlediğini göstermiştir (Köseoğlu, 2019).

Bütün canlılarda olduğu gibi, bitkilerde de gen ifadesinin biyolojik kontrol düzenlemeleri en temel durumdur. Transkripsiyon faktörleri, bitkilerin planlama, gelişme, bitki organı farklılaşması, stoma gelişimi, yanal organ oluşumu, çiçek oluşumu ve çeşitli çevresel sinyallere cevap verme gibi birçok fonksiyona sahip olması için gereklidir (Yanagisawa, 1998).

Sonuç olarak; şimdiye kadar yapılan çalışmalarda toprak ve bitkiler için toksik bakır seviyeleri iyi bir şekilde tespit edilmiştir. Ayrıca bakırın temel ve toksik seviyeleri, farklı redoks durumu, çeşitli toprak koşulları ve bitki türleri için değişebileceği bazı çalışmalarla kanıtlanmıştır. Örneğin, $\mathrm{Cu}^{+}$ve $\mathrm{Cu}^{+2}$ arasındaki biyotransformasyon ve ayn zamanda ilişkili toksisite, farklı bitki türleri arasında büyük ölçüde farklılık gösterir. Benzer şekilde, asidik ve alkali toprak koşulları, Cu'ın toprak-bitki transferi ve bitki büyümesi üzerindeki etkileri değiştirebilir.

Hassas bitkilerin bakır alım kapasitesi bitkinin toleransına göre değişebilir. $\mathrm{Bu}$ nedenlerden dolayı çeşitli redoks durumları, farklı toprak koşulları, bitki türleri ve diğer ilişkili bazı faktörler için bakırın eşik seviyelerini bilmek önem 
taşımaktadır. Farklı biyokimyasal reaksiyonlarda, dokulardaki temel rolü sebebiyle uygun bitki büyümesinin sağlanabilmesi için farklı bitki doku ve organlarına kontrollü bir bakır transferi çok önemli ve zorunludur. Bakırın gerekli olduğu dokulara, organlara taşınmasına aracılık eden çeşitli taşıyıcı proteinlerin katılımı iyi bilinmektedir. Fakat, farklı taşıyıcı proteinlerin rolü ayrıca ilişkili genlerin ekspresyonu, özellikle farklı bitki türlerinde tam manasıyla açık olarak ifade edilmemiştir. Farklı bitki türlerinde uygulanan çeşitli $\mathrm{Cu}$ seviyeleri altında farklı doku ve organlarda çeşitli genlerin ve taşıyıcı proteinlerin ekspresyonu ve rolü ile ilgili daha fazla araştırma gereklidir.

Bakır redoks-aktif bir metaldir ve Fenton reaksiyonu sayesinde bitkilerde ROS oluşturur. ROS, antioksidan ve redoks dengesine bağlı olarak farklı biyomoleküllerde ve biyokimyasal işlemlerde faydalı veya toksik olabilir. Bununla birlikte, uygulanan farklı bakır seviyeleri, farklı toprak koşulları, bitki türleri, bitkiler içinde ROS üretimi ve detoksifikasyon mekanizmalarının aktivasyonu için doz-tepki etkileşimleri tam olarak açıklanmamıştır. Bakırın toksik olduğu koşullarda bazı bitki türlerinde, farklı enzimatik ve enzimatik olmayan antioksidanlar aktiftir. Ayrıca genetik ve hücresel düzeyde birçok antioksidanın aktivasyon hızı ve de yoğunluğu ile ilgili mekanizmalar net olarak açıklanmamıştır. Bitkiler için mineral beslenmenin yaşamsal önemiyle ilgili bazı bilimsel sorular tam olarak hala netleşmemiştir. Örneğin farklı bitki türleri, temel hücresel reaksiyonlara dengeli ayrıca toksik düzeydeki bakır alınmasına nasıl aracılık eder? Farklı bitki türleri, farklı dokularda toksik bakır birikimini nasıl engeller? $\mathrm{Bu}$ sorulara daha fazla cevap bulunmalıdır. Ayrıca bakır toksisitesi altında bitkiye aracılık eden çok az transkripsiyon faktörü bulunmuştur ve incelenmiştir. Bitkide fazla bakır alımına aracılık eden şaperonlar ve transkripsiyon faktörleri ile ilgili mekanizmalar daha çok incelenmelidir. Böylelikle bakırın, etki ettiği stresle ilgili yolaklar ve bitkilerin stresle başa çıkma yolları daha iyi aydınlatılmış olacaktır.

\section{Teşekkür}

$\mathrm{Bu}$ çalışmanın hazırlanmasında desteklerini aldığım Sayın Dr. Fatma Şeyma GÖKDEMIR'e teşekkürlerimi sunarım. 


\section{Kaynaklar}

Ameh T, Sayes C (2019). The potential exposure and hazards of copper nanoparticles: A review. Environmental Toxicology and Pharmacology 71: 103220.

Balandin T, Castresana C (2002). AtCOX17, an Arabidopsis homolog of the yeast copper chaperone COX17. Plant Physiol 129: 1852-1857.

Baldi E, Miotto A, Ceretta CA, Brunetto G, Muzzi E, Sorrenti G, Quartieri M, Toselli M, (2018a). Soil application of $\mathrm{P}$ can mitigate the copper toxicity in grapevine: physiological implications. Scientia Horticulturae 238: 400-407.

Baldi E, Miotto A, Ceretta CA, Quartieri M, Sorrenti G, Brunetto G, Toselli M (2018b). Soilapplied phosphorous is an effective tool to mitigate the toxicity of copper excess on grapevine grown in rhizobox. Scientia Horticulturae 227: 102-111.

Batool R, Hameed M, Ashraf M, Ahmad MSA, Fatima S (2015). Physio-anatomical responses of plants to heavy metals. In: M Öztürk, M Ashraf, A Aksoy, M.SA Ahmad (Eds.) Phytoremediation For Green Energy 79-96.

Bazihizina N, Colzi I, Giorni E, Mancuso S, Gonnelli C (2015). Photosynthesizing on metal excess: Copper differently induced changes in various photosynthetic parameters in copper tolerant and sensitive Silene paradoxa L. populations. Plant Science 232: 67-76.

Bernal M, Casero D, Singh V, Wilson GT, Grande A, Chen H, Dodani SC, Pellegrini M, Huijser P, Connolly EL, Merchant SS, Krämer U (2012). Transcriptome sequencing identifies SPL7-regulated copper acquisition genes FRO4/FRO5 and the copper dependence of iron homeostasis in Arabidopsis. Plant Cell 24: 738-761.

Birkenbihl RP, Jach G, Saedler H, Huijser P (2005) Functional dissection of the plant-specific sbp-domain: overlap of the dna-binding and nuclear localization domains. Journal of Molecular Biology 352(3): 585-596.

Bock KW, Honys D, Ward JM, Padmanaban S, Nawrocki EP, Hirschi KD, Twell D, Sze H (2006). Integrating membrane transport with male gametophyte development and function through transcriptomics. Plant Physiol 140: 1151-1168.

Bouazizi H, Jouili H, Geitmann A, ElFerjani E (2010). Copper toxicity in expanding leaves of Phaseolus vulgaris L.: antioxidant enzyme response and nutrient element uptake. Ecotoxicology and Environmental Safety 73: 1304-1308.

Buapet P, Shah Mohammadi N, Pernice M, Kumar M, Kuzhiumparambil U, Ralph P (2018). Excess copper promotes photoinhibition and modulates the expression of antioxidant related genes in Zostera muelleri. Aquatic Toxicology 207.

Cambrollé J, García Fernández JL, Ocete R, Figueroa E, Cantos M (2013). Growth and photosynthetic responses to copper in wild grapevine. Chemosphere 93: 294-301.

Cambrollé J, García Fernández JL, Ocete R, Figueroa E, Cantos M (2013). Growth and photosynthetic responses to copper in wild grapevine. Chemosphere 93: 294-301.

Cao Y, Ma C, Chen G, Zhang J, Xing B (2017). Physiological and biochemical responses of Salix integra Thunb. under copper stress as affected by soil flooding. Environmental Pollution 225: 644-653.

Chaney WR, Strickland RC (1984). Relative toxicity of heavy metals to red pine pollen germination and germ tube elongation. J Environ Quai 13: 391-394. 
Chen CC, Chen YY, Tang IC, Liang HM, Lai CC, Chiou JM (2011). Arabidopsis SUMO E3 ligase SIZ1 is involved in excess copper tolerance. Plant Physiol 156: 2225-2234.

Chu HH, Chiecko J, Punshon T, Lanzirotti A, Lahner B, Salt DE, Walker EL (2010). Successful reproduction requires the function of Arabidopsis YELLOW STRIPELIKE1 and YELLOW STRIPE-LIKE3 metal-nicotianamine transporters in both vegetative and reproductive structures. Plant Physiology 154(1): 197-210.

Clarkson DT, Hanson JB (1980). The mineral nutrition of higher plants. Annual Rev PI Physiol 31: 239-298.

Cox RM, Hutchinson TC (1980). The response of root acid phosphatase activity to heavy metal stress in tolerant and non-tolerant clones of two grass species. New Phytol 86: 359-364.

de Freitas, Tielle Abreu França, Marcel Giovanni Costa; de Almeida, Alex-Alan Furtado; de Oliveira, Sérgio José Ribeiro; de Jesus, Raildo Mota; Souza, Vânia Lima; dos Santos Silva, José Victor; Mangabeira, Pedro Antônio (2015). Morphology, ultrastructure and mineral uptake is affected by copper toxicity in young plants ofInga subnudasubs luschnathiana (Benth.) T.D. Penn. Environmental Science and Pollution Research, 22(20), 15479-15494.

Du Q, Zhao XH, Xia L, Jiang CJ, Wang XG, Han Y, Wang J, Yu HQ (2019). Effects of potassium deficiency on photosynthesis, chloroplast ultrastructure, ROS, and antioxidant activities in maize (Zea mays L.). Journal of Integrative Agriculture 18: $395-406$.

Fichman Y, Miller G, Mittler R (2019). Whole-plant live 1maging of reactive oxygen species. Molecular Plant 12: 1203-1210.

Garcia-Molina A, Xing S, Huijser P (2014) A conserved KIN17 curved DNA-binding domain protein assembles with SQUAMOSA PROMOTER-BINDING PROTEIN-LIKE7 to adapt Arabidopsis growth and development to limiting copper availability. Plant Physiol 164(2): 828-840.

Gayomba SR, Jung HI, Yan J, Danku J, Rutzke MA, Bernal M, Krämer U, Kochian LV Salt DE, Vatamaniuk OK (2013). The CTR/COPT-dependent copper uptake and SPL7dependent copper deficiency responses are required for basal cadmium tolerance in $A$. thaliana. Metallomics 5: 1262-1275.

Gomes M, Smedbol É, Chalifour A, Hénault-Ethier L, Labrecque M, Lepage L, Lucotte, M, Juneau P (2014). Alteration of plant physiology by glyphosate and its by-product aminomethylphosphonic acid: An overview. Journal of Experimental Botany 65.

Gong Q, Wang L, Dai T, Zhou J, Kang Q, Chen H, Li K, Li Z (2019). Effects of copper on the growth, antioxidant enzymes and photosynthesis of spinach seedlings. Ecotoxicology and Environmental Safety 171: 771-780.

Gökdemir FŞ (2019). Fasulye (Phaseolus vulgaris L.) bitkisinde Whirly ve ARR-B genlerinin genom düzeyinde tanımlanması, karakterizasyonu ve biyotik stres cevabı ile olan ilişkilerinin gen ifadesi düzeyinde belirlenmesi. Ankara Üniversitesi.

Gupta B, Mukherji S (1977). Effects of toxic concentrations of copper on growth and metabolism of rice seedlings. Z Pflanzen Physiol 82: 95-106. 
Henriqnes F (1984). Effects of copper and iron deficiency on sugar beet chloroplasts ultrastructure. Actas del Congreso Iberico de Microscopia Electronica 75.

Henriqnes F (1989). Effects of copper deficiency on the photosynthetic apparatus of sugar beet (Beta vulgaris L.). J Pl Physiol 135: 453-458.

Himelblau E, Mira H, Lin SJ, Culotta VC, Peñarrubia L, Amasino RM (1998). Identification of a functional homolog of the yeast copper homeostasis gene ATX1 from Arabidopsis. Plant Physiol 117: 1227-1234.

Hippler FWR, Mattos JR D, Boaretto RM, Williams LE (2018). Copper excess reduces 1463 nitrate uptake by Arabidopsis roots with specific effects on gene expression. Journal of Plant Physiology 228: 158-165.

Hogan GD, Ranser WE (1981). Role of copper binding, absorption and translocation in copper tolerance of Agrostis gigantea Roth J Exp Bot 32: 27-36.

Jaime-Pérez N, Kaftan D, Bína D, Bokhari SNH, Shreedhar S, Küpper H (2019). Mechanisms of sublethal copper toxicity damage to the photosynthetic apparatus of Rhodospirillum rubrum. Biochimica et Biophysica Acta (BBA)- Bioenergetics 1860: 640-650.

Jung HI, Gayomba SR, Rutzke MA, Craft E, Kochian LV, Vatamaniuk OK (2012). COPT6 is a plasma membrane transporter that functions in copper homeostasis in Arabidopsis and is a novel target of SQUAMOSA promoter-binding protein-like 7. J Biol Chem 287: $33252-33267$.

Kapoor D, Singh S, Kumar V, Romero R, Prasad R, Singh J (2019). Antioxidant enzymes regulation in plants in reference to reactive oxygen species (ROS) and reactive nitrogen species (RNS). Plant Gene 19: 100182.

Kopittke P, Pax C Blamey F, McKenna B, Wang P, Menzies N (2011). Toxicity of metals to roots of cowpea in relation to their binding strength. Environ Toxicol Chem 30: 18271833.

Köseoğlu E (2019). Ağır metal stresine maruz kalmış fasulye çeşitlerinde CAMTA ve YABBY genlerinin gen ifadesi düzeyinde incelenmesi. Ankara Üniversitesi.

Krayem M, Deluchat V, Hourdin P, Fondanèche P, Lecavelier Des Etangs F, Kazpard V, Moesch C, Labrousse P (2018). Combined effect of copper and hydrodynamic conditions on Myriophyllum alterniflorum biomarkers. Chemosphere 199: 427-434.

Kropat J, Tottey S, Birkenbihl RP, Depège N, Huijser P, Merchant S (2005). A regulator of nutritional copper signaling in Chlamydomonas is an SBP domain protein that recognizes the GTAC core of copper response element. Proceedings of the National Academy of Sciences of the United States of America 102(51):18730-18735.

Kumar A, Gahoi P, Verma N (2019). Simultaneous scavenging of Cr (VI) from soil and facilitation of nutrient uptake in plant using a mixture of carbon microfibers and nanofibers. Chemosphere 124760.

Kumar A, Huang B, Sivapatham P (2000). Soil pH affects copper fractionation and phytotoxicity. Soil Science Society of America Journal - SSSAJ 64.

Larcher W (1980). Ecological Plant Physiology 2: 303.

Lastra OA, Chneca C., Gonzez M, Lachica J., (1987). E1 cobre como nutriente de la pinata. Anales Edafol. Agrobiol. 46: 1005-1020. 
Lee TI, Young RA (2000). Transcription of eukaryotic protein-coding genes. Annu Rev Genet 34: 77-137.

Lillo F, Ginocchio R, Ulriksen C, Dovletyarova EA, Neaman A (2019). Evaluation of connected clonal growth of Solidago chilensis as an avoidance mechanism in copperpolluted soils. Chemosphere 230: 303-307.

Lwalaba JLW, Louis LT, Zvobgo G, Fu L, Mwamba TM, Mukobo Mundende RP, Zhang G, (2019). Copper alleviates cobalt toxicity in barley by antagonistic interaction of the two metals. Ecotoxicology and Environmental Safety 180: 234-241.

Marcec MJ, Gilroy S, Poovaiah BW, Tanaka K (2019). Mutual interplay of $\mathrm{Ca}^{2+}$ and ROS signaling in plant immune response. Plant Science 283: 343-354.

Marques DM, da Silva AB, Mantovani JR, Magalhães PC, de Souza TC (2019). Root morphology and leaf gas exchange in Peltophorum dubium (Spreng.) Taub. (Caesalpinioideae) exposed to copper-induced toxicity. South African Journal of Botany 121: 186-192.

Marques DM, Veroneze JV, da Silva A, Mantovani JR, Magalhães PC, de Souza TC (2018). Copper toxicity on photosynthetic responses and root morphology of Hymenaea courbaril L. (Caesalpinioideae). Water, Air, \& Soil Pollution, 229(5): 138.

Marschner H (2011). Marschner's mineral nutrition of higher plants. Academic press.

Michaud A, Chappellaz C, Hinsinger P (2008). Copper phytotoxicity affects root elongation and iron nutrition in durum wheat (Triticum turgidum durum L.). Plant and Soil 310: $151-165$.

Mira H, Martínez-García F, Peñarrubia L (2001). Evidence for the plant-specific intercellular transport of the Arabidopsis copper chaperone CCH. Plant J. 25: 521-528.

Mostofa MG, Fujita M (2013). Salicylic acid alleviates copper toxicity in rice (Oryza sativa L.) seedlings by up-regulating antioxidative and glyoxalase systems. Ecotoxicology 22: 959-973.

Mwamba T, Li L, Gill RA, Islam F, Nawaz A, Ali DB, Farooq MA, Lwalaba J, Zhou W (2016). Differential subcellular distribution and chemical forms of cadmium and copper in Brassica napus. Ecotoxicology and Environmental Safety 134: 239-249.

Nanda R, Agrawal V (2018). Piriformospora indica, an excellent system for heavy metal sequestration and amelioration of oxidative stress and DNA damage in Cassia angustifolia Vahl under copper stress. Ecotoxicology and Environmental Safety 156: 409-419.

Natasha Shahid M, Khalid S, Bibi I, Bundschuh J, Niazi N, Dumat C (2020). A critical review of mercury speciation, bioavailability, toxicity and detoxification in soil-plant environment: Ecotoxicology and health risk assessment. Science of The Total Environment 711: 134749.

Nazir F, Hussain A, Fariduddin Q (2019). Hydrogen peroxide modulate photosynthesis and antioxidant systems in tomato (Solanum lycopersicum L.) plants under copper stress. Chemosphere 230: 544-558.

Neill SJ, Desikan R, Clarke A, Hurst RD, Hancock JT (2002). Hydrogen peroxide and nitric oxide as signalling molecules in plants. Journal of Experimental Botany 53: 1237-1247. 
Noctor G, Reichheld JP, Foyer CH (2018). ROS-related redox regulation and signaling in plants. Seminars in Cell \& Developmental Biology 80: 3-12.

Pasternak T, Rudas V, Potters G, Jansen MAK (2005). Morphogenic effects of abiotic stress: reorientation of growth in Arabidopsis thaliana seedlings. Environ Exp Bot 53: 299314.

Pourrut B, Shahid M, Dumat C, Winterton P, Pinelli E (2011). Lead uptake, toxicity, and detoxification in plants. Rev Environ Contam Toxicol 113-136.

Qi J, Wang J, Gong Z, Zhou JM (2017). Apoplastic ROS signaling in plant immunity. Curr Opin Plant Biol 38: 92-100.

Quinn JM, Barraco P, Eriksson M, Merchant S (2000). Coordinate copper- and oxygenresponsive Cyc6 and Cpx1 expression in Chlamydomonas is mediated by the same element. J Biol Chem 275: 6080-6089.

Raldugina G, Krasavina M, Fjodorovna Lunkova N, Anatoljevna Burmistrova N (2016). Resistance of Plants to Cu Stress 69-114.

Rose T, Kretzschmar T, Liu L, Lancaster G, Wissuwa M (2016). Phosphorus deficiency alters nutrient accumulation patterns and grain nutritional quality in rice. Agronomy 6, 52.

Ryszka P, Lichtscheidl I, Tylko G, Turnau K (2019). Symbiotic microbes of Saxifraga stellaris ssp. alpigena from the copper creek of Schwarzwand (Austrian Alps) enhance plant tolerance to copper. Chemosphere 228: 183-194.

Sancenón V, Puig S, Mateu-Andrés I, Dorcey E, Thiele DJ, Peñarrubia L (2004). The Arabidopsis copper transporter COPT1 functions in root elongation and pollen development. J Biol Chem 279: 15348-15355.

Sancenón V, Puig S, Mira H, Thiele DJ, Peñarrubia L (2003). Identification of a copper transporter family in Arabidopsis thaliana. Plant Mol Biol 51: 577-587.

Schrimpf E (1984). Air pollution patterns in two cities of Colombia, S.A., according to trace substances content of an epiphyte (Tillandsia recurvata L.). Water Air Soil Pollut 24: $85-101$.

Shahid M (2017). Biogeochemical behavior of heavy metals in soil-plant system. Higher Education Commission of Pakistan 1-196.

Shahid M, Khalid S, Abbas G, Shahid N, Nadeem M, Sabir M, Aslam M, Dumat C (2015). Heavy metal stress and crop productivity. Crop Production and Global Environmental Issues. Springer, 1-25.

Sharma R, Bhardwaj R, Thukral AK, Al-Huqail AA, Siddiqui MH, Ahmad P (2019). Oxidative stress mitigation and initiation of antioxidant and osmoprotectant responses mediated by ascorbic acid in Brassica juncea L. subjected to copper (II) stress. Ecotoxicology and Environmental Safety 182: 109436.

Sheldon A, Menzies N (2005). The effect of copper toxicity on the growth and root morphology of Rhodes grass (Chloris gayana Knuth.) in resin buffered solution culture. Plant and Soil 278: 341-349.

Shkolnik MY (1984). Trace elements in plants. Elsevier, Amsterdam. 463 pp. 
Silva JC, Echeveste P, Lombardi AT (2018). Higher biomolecules yield in phytoplankton under copper exposure. Ecotoxicology and Environmental Safety 161: 57-63.

Silva JC, Echeveste P, Lombardi AT (2018). Higher biomolecules yield in phytoplankton under copper exposure. Ecotoxicology and Environmental Safety 161: 57-63.

Singh D, Kumar A (2016). Impact of 1rrigation using water containing $\mathrm{CuO}$ and $\mathrm{ZnO}$ nanoparticles on Spinach oleracea grown in soil media. Bulletin of Environmental Contamination and Toxicology 97.

Smilde KW (1981). Heavy metal accumulation in crops grown on sewage sludge amended with metal salts. Plant \& Soil 62: 3-14.

Sommer AL (1931). Copper as an essential for plant growth. Plant Physiol 6: 339-345.

Sommer F, Kropat J, Malasarn D, Grossoehme NE, Chen X, Giedroc DP, Merchant SS (2010). The CRR1 nutritional copper sensor in Chlamydomonas contains two distinct metal-responsive domains. Plant Cell 22: 4098-4113.

Srinivas US, Tan BWQ, Vellayappan BA, Jeyasekharan AD (2018). ROS and the DNA damage response in cancer. Redox Biology 101084.

Stiborova M, Doubravovfi M., Brezinovt A., Friedrich A. (1986a). Effect of heavy metal ions on growth and biochemical characteristics of photosynthesis of barley (Hordeum vulgare L.). Photosynthetica 20: 418-425.

Stiborova M, Hrodmadkova R, Leblova S (1986b). Effects of ions of heavy metals on the photosynthetic characteristics of maize (Zea mays L.) Biologia 41: 1221-1228.

Verma DPS (1992). Control of plant gene expression. The CRC Press, Boca Raton, Florida.

Wong MH, Bradshaw AD (1982). A comparison of the toxicity of heavy metals, using root elongation of ryegrass, Lolium perenne. New Phytol 91: 255-261.

Yadav P, Kaur R, Kanwar MK, Sharma A, Verma V, Sirhindi G, Bhardwaj R (2018). Castasterone confers copper stress tolerance by regulating antioxidant enzyme responses, antioxidants, and amino acid balance in B. juncea seedlings. Ecotoxicology and Environmental Safety 147: 725-734.

Yalcinkaya T, Uzilday B, Ozgur R, Turkan I, Mano JI (2019). Lipid peroxidation-derived reactive carbonyl species (RCS): Their interaction with ROS and cellular redox during environmental stresses. Environmental and Experimental Botany 165: 139-149.

Yamasaki H, Hayashi M, Fukazawa M, Kobayashi Y, Shikanai T (2009). SQUAMOSA Promoter Binding Protein-Like7 is a central regulator for copper homeostasis in Arabidopsis. Plant Cell 21: 347-361.

Yanagisawa S, Sheen J (1998). Involvement of maize Dof zinc finger proteins in tissuespecific and lightregulated gene expression. Plant Cell 10: 75-89.

Younis M, Tourky S, Elsharkawy S (2018). Symptomatic parameters of oxidative stress and antioxidant defense system in Phaseolus vulgaris L. in response to copper or cadmium stress. South African Journal of Botany 117, 207-214.

Yuan HM, Xu HH, Liu WC, Lu YT (2013). Copper regulates primary root elongation through PIN1-mediated auxin redistribution. Plant and Cell Physiology 54(5): 766-778. 
Zhang D, Li C (2019). Genotypic differences and glutathione metabolism response in wheat exposed to copper. Environmental and Experimental Botany 157: 250-259.

Zhang H, Yang J, Wang W, Li D, Hu X, Wang H, Wei M, Liu Q, Wang Z, Li C (2015). Genome-wide identification and expression profiling of the copper transporter gene family in Populus trichocarpa. Plant Physiology and Biochemistry 97: 451-460. 